\title{
INFLUENCE OF DRIP IRRIGATION ON GROWTH AND YIELD OF COD X WCT COCONUT (COCOS NUCIFERA L.) HYBRID
}

\author{
R. Dhanapal ${ }^{\prime \prime}$, H. P. Maheswarappal/ P. Subramanian and Ajay Kumar Upadhyay ${ }^{l /}$
}

\begin{abstract}
A field experiment on drip irrigation for Chowghat Orange Dwarf X West Coast Tall (COD X WCT) coconut hybrid was conducted in laterite soil at Central Plantation Crops Research Institute, Kasaragod (Kerala, India) to study the drip irrigation requirement and its influence on growth and yield. The treatments included were three levels of drip irrigation (at 33, 66 and $100 \% E_{0}$ daily), basin irrigation $\left(100 \% E_{0}\right)$ and rainfed control. The experimental results revealed that annual leaf production and leaf nutrient status of coconut palm was significantly higher in the irrigated treatments compared to the rainfed control. The female flower production and nut yield with 66 per cent of Eo was on par with 100 per cent of Eo through drip and 100 per cent of Eo through basin irrigation and significantly superior compared to drip irrigation at 33 per cent of $E_{0}$ and rainfed control. Drip irrigation equal to 66 per cent of open pan evaporation (Eo) proved to be the economically efficient method of irrigation with water saving of 34 per cent compared to 100 per cent of Eo through basin and drip method.
\end{abstract}

\section{Keywords: Coconut hybrid, Drip irrigation, Growth and Nut yield}

\section{INTRODUCTION}

Coconut (Cocos nucifera L.) is a high value commercial crop grown in 92 countries with a total area coverage of 11.91 million ha producing 54130 million nuts annually during the year 1999 . India, Indonesia, Philippines and Sri Lanka are the four major global players, which together contribute 78 per cent of the world production. With an area of 1.91 million ha, India's share to the global coconut area is 16 per cent. India is now the leading coconut producing country in the world with a production of 15000 million nuts and percentage share of 27.6 followed by Indonesia and Philippines. In productivity too India ranks in the forefront with a productivity of
7821 nuts per ha whereas the world productivity is as low as 4294 nuts per ha (Rethinam, 2001).

In India, Andhra Pradesh stands in the forefront with the productivity of 19575 nuts per ha while in Kerala it is as low as 6188 nuts per ha (Rethinam, 2001) mainly because of the fact that, it is being grown as rain dependent crop and prevalence of root (wilt) disease. Though Kerala falls under heavy rainfall zone the variability of rainfall coupled with inadequate irrigation resources and poor water management results in mild to severe stress on coconut palms between the months of December and May resulting in lower productivity. Coconut grown in droughtprone gravely soils is often subjected to periodic moisture deficit during the dry season (Carr, 1992).

1/ Central Plantation Crops Research Institute, Kasaragod - 671 124, Kerala, India 
The importance of irrigating coconut for a sustained yield has been emphasised (Abeywardena, 1971, Varadan and Madhava Chandran, 1991 and Dhanapal et al., 2000b). Among the irrigation systems, drip irrigation is gaining importance as it maintain the soil moisture availability and air balance in the root zone of coconut near field capacity throughout the dry season and saves irrigation water (Vidhana Arachchi, 1998). Dorota and Forrest (1996) reported that drip irrigation wets only a limited portion of the potential soil-root volume which would be adequate for most plants to perform well along with minimum evaporation loss of water.

Keeping in view the above facts, a field investigation was initiated at Central Plantation Crops Research Institute, Kasaragod, in laterite soil with the objectives to study the drip irrigation requirement and its influence on growth and yield of COD (Chowghat orange dwarf) X WCT (West coast tall) coconut hybrid.

\section{MATERIALS AND METHODS}

\subsection{Experimental site}

The experiment was conducted at Central Plantation Crops Research Institute (CPCRI), Kasaragod, Kerala (India), which is situated at $12^{\circ}$ $30^{\circ} \mathrm{N}$ latitude and $75^{\circ} 00^{\circ} \mathrm{E}$ longitude at an elevation of $10.7 \mathrm{~m}$ above mean sea level.

The average rainfall received in the area is $3400 \mathrm{~mm}$, out of which, 86 per cent is received during the four monsoon months (JuneSeptember) and the period from December to middle May remains rainless. The maximum temperature ranges between $28.8^{\circ} \mathrm{C}$ and $33.1^{\circ} \mathrm{C}$ and minimum temperature varies between $19.4^{\circ} \mathrm{C}$ and $24.4^{\circ} \mathrm{C}$. The relative humidity ranges between 81 per cent and 94 per cent and the maximum open pan evaporation is recorded during the months of March to May (5.0 to $5.3 \mathrm{~mm}$ per day).

The soil of the experimental field was classified as laterite soil with gravely-clay texture containing on an average 56 per cent gravels. Top layer contains equal amount of sand and clay but clay fraction dominated in lower layer.

\subsection{Experimental details}

The experiment was conducted in randomised complete block design with four replications and three palms per treatment. The treatments composed of:
T1: Drip irrigation at 33 per cent $\mathrm{E}_{0}$ (open pan evaporation) daily

$\mathrm{T} 2$ : Drip irrigation at 66 per cent $\mathrm{E}_{0}$ daily

T3: Drip irrigation at 100 per cent $\mathrm{E}_{0}$ daily

T4: Basin irrigation at 100 per cent of $\mathrm{E}_{0}$ applied once in four days through hose pipe, and

T5 : Rainfed control.

The quantity of water applied in each treatments was calculated based on the effective root zone of coconut. The $1.8 \mathrm{~m}$ radius of coconut basin was taken as the effective root zone as suggested by earlier workers (Kushwah et al. 1973 and Maheswarappa et al. 2000). The quantity of water applied was based on daily mean monthly open pan evaporation $\left(\mathrm{E}_{0}\right)$ (Twenty years average) during December-January and February-May months (Table 1). The daily mean monthly open evaporation values during the months of December-January was $4.2 \mathrm{~mm}$ and February-May was $5.0 \mathrm{~mm}$ respectively.

The drip irrigation system consisted of an overhead water tank and the outlet was connected with water filter along with main pipeline. From the main pipeline, the laterals $(16 \mathrm{~mm}$ Low Density Poly Ethylene (LDPE) pipes) of convenient length were laid with end cap. At the base of the each palm four emitters were placed one metre away from the bole at equidistance with the help of $4 \mathrm{~mm}$ LDPE microtubes. The water from the emitters was allowed to drip at the rate of 2 litre per hour upto the $30 \mathrm{~cm}$ depth by putting the emitters in $30 \mathrm{~cm}^{3}$ pits with the help of conduit pipe. Under basin irrigation, water was applied in basin of $1.8 \mathrm{~m}$ radius as per the treatment.

The coconut palms were planted during

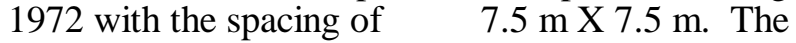
adult palms were supplied with 500:320:1200 $\mathrm{g}$ NPK per palm per year in the form of urea, mussoorie rock phosphate, and muriate of potash applied in two splits, $1 / 3^{\text {rd }}$ during April-May and 
$2 / 3^{\text {rd }}$ during September-October. The drip irrigation treatments were imposed as per treatments from 1993 onwards during non-rain periods of December to May.

The annual leaf production per palm was recorded during the experimental period every year. Coconut leaf samples were collected from the index leaf $\left(14^{\text {th }}\right.$ leaf) during 1999 and analysed for $\mathrm{N}, \mathrm{P}$ and $\mathrm{K}$ content by adopting standard procedures (Jackson, 1973). Female flower production and nut yield from each palm was recorded separately during each harvest every year. The data recorded on various characters were subjected to Fisher's method of analysis of variance and interpretation of data was done as per the procedure given by Gomez and Gomez (1984).

\section{RESULTS AND DISCUSSION}

\subsection{Leaf production}

The average annual leaf production ranged from 11.2 to 13.2 leaves per palm under different treatments (Table 2). The irrigated treatments irrespective of the method and quantity of water applied, produced similar results (12.5 to 13.2), which varied statistically from the unirrigated control (11.2) which may be attributed to adequate supply of water and inturn, nutrients. Dhanapal et al. (2000b) have reported the enhanced rate of leaf production under irrigated palms compared to rainfed palms under littoral sandy soil condition.

\subsection{Leaf nutrient status}

The leaf analysis for the major nutrients viz., $\mathrm{N}, \mathrm{P}$ and $\mathrm{K}$ indicated that there was significant difference among the irrigation treatments (Table 2). N, P and $\mathrm{K}$ contents were found to be statistically higher in the irrigated treatments compared to rainfed control. This clearly indicates that water is the key factor which affects nutrient uptake from the soil. Under drip irrigation, the drippers were placed $100 \mathrm{~cm}$ away from the bole and highest moisture extraction might have resulted in better uptake of nutrients. Higher uptake of $\mathrm{N}$ and $\mathrm{K}$ by coconut in littoral sandy soil under irrigated condition compared to rainfed control was also reported by Dhanapal et al. (2000b). Better uptake of nutrients under irrigated condition might be because of more number of main and fine roots development compared to rainfed control (Dhanapal et al., 2000a). Vidhana Arachchi (1998) also reported that, roots at a distance of 50-100 $\mathrm{cm}$ away from the base of the palm were responsible for most of the water absorption, and the highest moisture extraction was observed at $100 \mathrm{~cm}$ distance in gravely soils. Higher root activity in olive trees under drip irrigation has been reported by Fernandez et al., (1991). In young arecanut palms also, higher number of main roots and feeder roots under drip irrigation method has been reported (Sujatha and Abdul Haris, 2000). Roots intercept more nutrient ions when grown in moist soil with adequate moisture than in dry soil, because root growth is more extensive. Mass flow of soil water to supply the transpiration stream, transports most of the nitrates to the roots (Tisdale et al., 1985). Higher uptake of $\mathrm{K}$ under adequate soil moisture condition was due to the increased solubility and better availability of the nutrient. Under rainfed condition, the nutrient uptake was statistically lower and this might be due to the fact that cells of the absorption zone of coconut roots grown in gravely soils become inactive by suberization and dehydration during dry weather, thus affecting the nutrient and water absorption process (Vidhana Arachchi, 1996).

\subsection{Female flower production and Nut Yield}

The pre experimental data on flower production and nut yield for the period 1991-1993 was non significant among the treatments and the average yield ranged from 31.7 to 37.3 nuts per palm per year.

Pooled data on female flower production for six years (1993-1999) differed statistically significant among the treatments (Table 3). Irrigation treatments recorded statistically higher female flowers compared to rainfed control. Among irrigation treatments, drip irrigation at 33 per cent of $E_{0}$ recorded statisticaly less female flowers and was on par with 66 per cent of $E_{0}$ drip irrigation treatment. Abeywardena (1979) and Venkitaswamy et al. (1997) also reported increase in female flower production under irrigated condition.

Pooled data on nut yield for six years (1993-1999) differed statistically significant among irrigation treatments and rainfed control. Drip irrigation at 33 per cent of $\mathrm{E}_{0}$ recorded statistically lower nut yield compared to other 
irrigation treatments and was on par with rainfed control. Nut yield recorded at 66 per cent and 100 per cent of $E_{0}$ through drip or basin irrigation were statistically on par with each other. This clearly indicated that drip irrigation at 33 per cent of $\mathrm{E}_{0}$ failed to produce significant increased in yield, may be due to the fact that the water applied could not meet the water requirement of the palm as indicated by lower stomatal conductance, transpiration rate and net photosynthesis (Anon., 1995 and 1997). Where as at higher levels of irrigation, there was increase in photosynthesis, transpiration rate and stomatal conductance which resulted in higher nut yield. Rajagopal et al. (1989) also reported greater stomatal resistance and epicuticular wax content and reduced transpiration rate, leaf water potential and reproductive dry matter under severely moisture stressed palms compared to well watered palms. Increase in nut yield was mainly attributed to production of more number of leaves and better uptake of nutrients under these treatments. Coconut palm in general produces one inflorescence/bunch in each leaf axil and thus higher leaf production will directly contribute towards increased nut yield. This clearly indicated that irrigation at 66 per cent of $E_{0}$ might be sufficient to produce maximum yield in laterite soil. Under rainfed condition, the hybrid palms suffer more as evidenced from lower physiological parameters like stomatal conductance, transpiration rate and photosynthesis (Anon., 1997). Similar type of results have been reported by many workers for Kerala conditions (Dhanapal et al. 2000b, Varadan and Madhava Chandran, 1991, Jose

Mathew et al. 1996, Saseendran and Jayakumar, 1988). According to Mahindapala (1987) in the dry zone of Sri Lanka, coconut requires 25 to 30 litres of water per day through drip method. under Trichy condition of Tamil Nadu (India), water requirement for coconut palm through drip irrigation ranged from 55 litres per day in December months to 115 litres per day in June months (Kulandaivelu, 1990). The main reason for 34 per cent of water saving in the 66 per cent of $\mathrm{E}_{0}$ through drip treatment compared to 100 per cent of $\mathrm{E}_{0}$ through drip or basin irrigation, was due to the fact that the water was applied at reduced quantity and thus the deep percolation loss was avoided. Subramanian et al., (1997) and Kapadiyal et al., (1998) also reported saving of irrigation to the tune of 40 to 50 per cent over surface irrigation by adopting drip irrigation. Though more water applied under 100 per cent $\mathrm{E}_{0}$ under drip and basin irrigation, it did not contribute towards higher yield, probably because the excess water might have moved beyond the root zone and was not used by the palms.

\section{CONCLUSIONS}

It is evident from the result that irrigation at higher levels improved growth, development, nutrient uptake and nut yield of the palms. As evident from the results the most economic irrigation level being the drip irrigation at 66 per cent of $E_{0}$ in terms of nut yield and water saving (Dhanapal et al. 2000b). Under Northern Kerala condition of India, irrigate coconut palms through drip irrigation at the rate of 27 litres of water per palm per day during December-January months and 32 litres of water per palm per day during February-May months for higher yields.

\section{ACKNOWLEDGEMENTS}

The author's wishes to thank the Director and the Head (Division of crop production) CPCRI, Kasaragod for their valuable support during the study. The assistance given by technical staff of the division is also greatly appreciated.

\section{REFERENCES}

Abeywardena, V .1971. Crop losses in coconut through button shedding and immature nut fall. Ceylon Coconut Planters Rev., 6,97-105.

Abeywardena, V .1979. Influence of watering on the yield of coconut. Ceylon-coconut Quarterly. 30 (3-4):91-100.

Anonymous .1995. Annual Report for 1994-95. Central Plantation Crops Research Institute, Kasagarod. pp. 47-48. 
Anonymous .1997. Annual Report for 1996-97. Central Plantation Crops Research Institute, Kasagarod. pp. 71-73.

Carr, M.K.V .1992. Report on a visit to Sri Lanka in the field of Plantation Crops Research, Coconut Research Institute, Sri Lanka.

Dhanapal R., Maheswarappa, H.P., Subramanian, P. 2000a. Response of coconut roots to the methods of irrigation in littoral sandy soil. Journal of Plantation Crops 28(3):208-211.

Dhanapal, R., Maheswarappa, H.P., Subramanian, P., Sairam, C. V., Gopalasundaram, P . 2000b. Micro irrigation technique for coconut in littoral sandy soil. In: Muraleedharan, N, Raj Kumar, R. (Eds.), Recent Advances in Plantation Crops Research. UPASI Tea Research Foundation, Tea Research Institute, Valparai, Tamil Nadu, India, Allied Publishers Limited, India. 181-185.

Dorota, Z. H. and Forrest, T .1996. Micro irrigation-the basics. Far Eastern Agriculture. Volume: September/October,17-19.

Fernandez, J. E., Moreno, F., Cabrera, F., Arrue, J. L. , Martin-Arada, J .1991. Drip irrigation, soil characteristics, root distribution and root activity of olive trees. Plant and Soil 133:239251.

Gomez, K. A., Gomez, A. A .1984. Statistical Procedures for Agricultural Research. $2^{\text {nd }}$ edn. A Wiley-Interscience Pub., John Wiley and Sons.

Jackson, M. L (1973) Soil Chemical Analysis, Prentice Hall of India Pvt. Ltd., New Delhi.

Jose Mathew, Pillai, G.R., Santhakumari, G., Kuruvilla Varughese .1996. Irrigation management on yield stabilization and annual productivity of coconut. J. Trop Agri., 34: 3335.

Kapadiyal, P.K., Koradiya, U.A. , Sarvaiya, R.B., Gandhi, A.P., Bhambhaniya, L.B., Lad, A.N., Raman, S .1998. Drip irrigation for coconut in south Saurashtra. In: Mathew N.M, Kuruvilla Jacob, C., Licy, J., Joseph, T., Meenattoor, J.R.(Eds.), Developments in Plantation Crops Research. Proceedings of $12^{\text {th }}$ symposium on
Plantation Crops, PLACROSYM XII, Kottayam, India,157-159.

Kulandaivelu, R .1990. Crop water requirement for coconut through drip system. Proceedings of $11^{\text {th }}$ International Congress on the use of plastics in agriculture, New Delhi, $26^{\text {th }}$ February-2 ${ }^{\text {nd }}$ March 1990, B.181-B.183.

Kushwah, B.L., Nelliat, E.V., Markose, V.T. and Sunny, A.F .1973. Rooting pattern of coconut. Indian Journal of Agronomy, 18(1): 71-74.

Maheswarappa, H.P., Subramanian, P. and Dhanapal, R .2000. Root distribution pattern of coconut (Cocos nucifera L.) in littoral sandy soil. Journal of Plantation Crops, 28(2): 164-166.

Mahindapala, R .1987. Irrigation in coconut. Coconut Bulletin (Sri Lanka) 4(2): 6-12.

Rajagopal, V., Ramadasan, A., Kasturi Bai, K.V. and Balasimha, D .1989. Influence of irrigation on leaf water relations and dry matter production in coconut palms. Irrigation Science, 10(1): 73-81.

Rethinam, P .2001. Coconut Industry in India. Coconut Development Board, Cochin, India. p. 37.

Saseendran, S.A. Jayakumar, M .1988. Consumptive use and irrigation requirement of coconut plantations in Kerala. Journal of Plantation Crops 16(2): 119-125.

Subramanian, P., Krishnasamy, S., Devasagayam, M. M .1997. Studies on the evaluation of drip irrigation in comparison with surface irrigation (basin) in coconut. South Indian Horticulture, 45(5-6):255-258.

Sujatha, S., Abdul Haris, A .2000. Root distribution as influenced by different methods of irrigation in young arecanut (Areca catechu L.) palms. Journal of Plantation Crops 28(2):117-122.

Tisdale,L. S., Nelson, W. L., Beaton, S. D .1985. Soil fertility and fertilisers. Macmillan Publishing Company, Inc. New York. pp. 700705 . 
Varadan, K. M., Madhava Chandran, K .1991. Irrigation requirement of coconut under drip method. In: Silas, E. G., Aravindakshan, M., Jose, A.J. (Eds.), Coconut breeding and management. Kerala Agricultural University, Trichur, India, 281-282.

Venkitaswamy, R., Christopher Lourduraj, A., Devasenapathy,P. Sridharan, C.S., Prabakaran, N.K., Madhiyazhagan, R .1997. Effect of drip irrigation on hybrid coconut. Madras Agric. J., 84 :591-593.

Vidhana Arachchi, L.P .1996. Characterization of
Vidhana Arachchi, L. P .1998. Preliminary requirements to design a suitable drip irrigation system for coconut (Cocos nucifera L.) in gravelly soils. Agricultural Water Management 38 :169-180.

Table 1. The quantity of water added in each treatment

\begin{tabular}{|c|c|c|}
\hline \multirow[b]{2}{*}{ Treatments } & \multicolumn{2}{|c|}{ Quantity of water (litres) } \\
\hline & Dec.-Jan. & Feb.-May \\
\hline $\begin{array}{l}\text { T1: Drip irrigation at } 33 \text { per cent } \mathrm{E}_{0} \\
\text { daily }\end{array}$ & 14 day $^{-1}$ palm $^{-1}$ & 16 day $^{-1}$ palm $^{-1}$ \\
\hline $\begin{array}{c}\text { T2: Drip irrigation at } 66 \text { per cent } \mathrm{E}_{0} \\
\text { daily }\end{array}$ & 27 day $^{-1}$ palm $^{-1}$ & 32 day $^{-1}$ palm $^{-1}$ \\
\hline $\begin{array}{l}\text { T3: Drip irrigation at } 100 \text { per cent } \\
\mathrm{E}_{0} \text { daily }\end{array}$ & 42 day $^{-1}$ palm $^{-1}$ & 50 day $^{-1}$ palm $^{-1}$ \\
\hline $\begin{array}{l}\text { T4: Basin irrigation at } 100 \text { per cent } \\
\text { of } \mathrm{E}_{0} \text { applied once in four } \\
\text { days through hose pipe }\end{array}$ & $\begin{array}{l}168 \text { once in } 4 \\
\text { days palm }\end{array}$ & $\begin{array}{l}200 \text { once in } 4 \text { days } \\
\text { palm }^{-1}\end{array}$ \\
\hline
\end{tabular}

physical properties of soils and studies on the development of coconut roots. The project report (12/175/149) submitted to the council for Agricultural Research Policy (CARP), Sri Lanka. 
Table 2. Annual leaf production, leaf nutrient content of CODxWCT as influenced by irrigation in laterite soil

\begin{tabular}{|l|c|c|c|c|}
\hline \multicolumn{1}{|c|}{ Treatments } & \multicolumn{2}{|c|}{$\begin{array}{c}\text { Annual leaf } \\
\text { production } \\
\text { (Mean of 1993- } \\
\text { 1999) }\end{array}$} & \multicolumn{3}{|c|}{$\begin{array}{c}\text { Leaf nutrient content } \\
\text { (During 1999) }\end{array}$} \\
\cline { 3 - 5 } & 12.5 & 1.73 & 0.118 & 1.57 \\
\hline T1: Drip irrigation at 33\% of $\mathrm{E}_{0}$ daily & 13.2 & 1.84 & 0.122 & 1.69 \\
\hline T2: Drip irrigation at $66 \%$ of $\mathrm{E}_{0}$ daily & 13.2 & 1.79 & 0.121 & 1.67 \\
\hline $\begin{array}{l}\text { T3: Drip irrigation at } 100 \% \text { of } \mathrm{E}_{0} \\
\text { daily }\end{array}$ & & & & $\mathrm{K}(\%)$ \\
\hline $\begin{array}{l}\text { T4: Basin irrigation at } 100 \% \text { of } \mathrm{E}_{0} \\
\text { once in 4 days }\end{array}$ & 13.1 & 1.81 & 0.118 & 1.75 \\
\hline T5: Rainfed control & 11.2 & 1.58 & 0.104 & 1.35 \\
\hline CD $(\mathrm{P}=0.05)$ & 0.72 & 0.17 & 0.010 & 0.152 \\
\hline
\end{tabular}

Table 3. Nut yield and Female flower production (Number/palm) as influenced by irrigation in CODXWCT under laterite soil.

\begin{tabular}{|l|c|c|c|c|}
\hline \multicolumn{1}{|c|}{ Treatments } & \multicolumn{2}{c|}{$\begin{array}{c}\text { Pre-experimental } \\
\text { (1991-93) }\end{array}$} & \multicolumn{2}{c|}{ Average of 1993-99 } \\
\cline { 2 - 5 } & $\begin{array}{c}\text { Female } \\
\text { flowers }\end{array}$ & Nut yield & $\begin{array}{c}\text { Female } \\
\text { flowers }\end{array}$ & Nut yield \\
\hline T1: Drip irrigation at 33\% of $\mathrm{E}_{0}$ daily & 80.3 & 32.6 & 210.4 & 72.8 \\
\hline T2: Drip irrigation at $66 \%$ of $\mathrm{E}_{0}$ daily & 103.2 & 31.7 & 252.2 & 113.6 \\
\hline T3: Drip irrigation at $100 \%$ of $\mathrm{E}_{0}$ daily & 110.7 & 33.4 & 266.5 & 119.7 \\
\hline $\begin{array}{l}\text { T4: Basin irrigation at } 100 \% \text { of } \mathrm{E}_{0} \text { once } \\
\text { in 4 days }\end{array}$ & 101.4 & 36.3 & 278.3 & 116.0 \\
\hline T5: Rainfed control & 99.3 & 37.3 & 188.0 & 58.6 \\
\hline CD $(\mathrm{P}=0.05)$ & $\mathrm{NS}$ & $\mathrm{NS}$ & 42.2 & 16.8 \\
\hline
\end{tabular}

